УДК 159.9:378

DOI:

Руслан Любчич, старший викладач кафедри фізичної підготовки та спорту Національної академії Національної Гвардії України

\title{
ПСИХОЛОГІЧНІ ТА ПЕДАГОГІЧНІ АСПЕКТИ ПРОФЕСІЙНОЇ КОМПЕТЕНТНОСТІ МАЙБУТНІХ ОФЦЕРІВ НАЦІОНАЛЬНОЇ ГВАРДІЇ УКРАЇНИ
}

Активні бойові дї̈ на сході, активна модернізація, поява принципово нових систем озброєння, ведення бойових дій та бойового застосування підрозділів Начіональної гвардії Украӥни впливають на завдання, які стоять перед Національною гвардією України. Пріоритетним завданням, яке стоїть перед військовим закладом вищої освіти (ВЗВО) при підготовиі майбутніх офіџерів Національної гвардії України є підготовка кваліфікованих кадрів, які в повній мірі будуть відповідати сучасним вимогам суспільства та війська. У статті проаналізовано різні підходи до визначення феномена "компетентність" та сформульовано низку положень, які є основними при розгляді даного поняття. Сформовано підходи до визначення змісту професійної освіти, обтрунтовано професійні вимоги до майбутніх офічерів Начіональної гвардії України.

Ключові слова: Національна гвардія Украӥни; військовий заклад вищої освіти; компетентність; прочес; військова освіта; фахівецьь; офіџер.

Jim. 6.

Ruslan Lyubchyn, Senior Lecturer of the Physical Training and Sports Department National Academy of the National Guard of Ukraine

\section{PSYCHOLOGICALAND PEDAGOGICALASPECTS OF PROFESSIONAL COMPETENCE OF FUTURE OFFICERS OF THE NATIONAL GUARD OF UKRAINE}

The circumstances that took place in Ukraine at the end of 2014 led to the restoration of the National Guard of Ukraine on the basis of parts of the internal troops of the Ministry of Internal Affairs of Ukraine, which most responded to the tasks of ensuring internal security by the nature of training, technical equipment and practical experience. In many countries, similar forces exist in order to solve the peacetime problems associated with the massive use of trained personnel and special equipment, in particular, the National Gendarmerie of the French Republic, the Gendarmerie of Romania, the Military People's Armed Police of the People's Republic of China, the Gendarmerie of Turkey, the Carabinieri of the Italian Republic, the Police of Readiness Germany, National Guard of California (USA). Active combat operations in the east, active modernization, the emergence of fundamentally new weapons systems, combat operations and combat application of the units of the National Guard of Ukraine have an impact on the tasks faced by the National Guard of Ukraine. The priority task facing the military institution of higher education (MIofHI) in the preparation of future officers of the National Guard of Ukraine is the training of skilled personnel who will fully meet the modern requirements of society and troops. The article analyzes various approaches to the definition of the "competence" phenomenon and formulates a number of provisions that are fundamental in the consideration of this concept. Approaches to determining the content of vocational education have been formed, the professional requirements for future officers of the National Guard of Ukraine have been substantiated.

Keywords: National Guard of Ukraine; military institution of higher education; competence; a process; military education; a specialist; an officer.

П остановка проблеми. Зважаючи на те, що керівництво держави націлене на переформатування силових структур під європейську модель, значущою стає потреба в підготовці керівника, здатного до організаційно-управлінської, аналітичної, плановоекономічної діяльності у військовій сфері, націленого на неперервне вдосконалення систем управління та підвищення їх ефективності в умовах стрімкого розвитку суспільства. Відповідно до цього потребують реформування модернізації системи військової освіти, які характеризуються пошуком та впровадженням шляхів, що забезпечать значне підвищення професійної компетентності майбутніх офіцерів. Оскільки ефективне вирішення завдань, які стоять перед Національною гвардією України (НГУ) напряму залежить від якості підготовки офіцерів, проблема управління формуванням професійної компетентності стає ключовим напрямом педагогічних досліджень.

Аналіз основних досліджень та публікацій. Теоретико-методологічною основою досліджень цієї проблеми є роботи авторів, які розкриваючи суть компетентністного підходу до навчання та виявляють різні аспекти формування професійної компетентності майбутніх офіцерів у ЗВО С.В. Райко, Л.А. Заїка, М.В. Закаблук, А.В. Турчинов та інші). 


\section{ПСИХОЛОГІЧНІ ТА ПЕДАГОГІЧНІ АСПЕКТИПРОФЕСІЙНОӤ КОМПЕТЕНТНОСТІ МАЙБУТНІХ ОФЩЕРІВ НАЦІОНАЛЬНОӤ ГВАРДІЇ УКРАЇНИ}

Безумовно ці роботи та дослідження заслуговують на увагу, але в багатьох 3 них недостатньо повно та розширено представлено аналіз процесу управління формуванням професійної компетентності. Окремі напрацювання 3 даного напрямку зустрічаються в дослідженнях О.М. Мартиненко, О.М. Маслій, І.С. Поліщук та інших.

Разом 3 тим, в педагогічній теорії та практиці цивільних та військових навчальних закладах $\epsilon$ брак розробленості навчально-теоретичних та організаційно методичних аспектів управління формуванням професійної компетентності майбутніх фахівців. Особливо відчувається дефіцит досліджень 3 даної тематики стосовно навчального процесу ВЗВО, який в силу своєї специфіки $є$ одним 3 найбільш важливим та складним об'єктом управління. Дана обставина залежить від того, що військовий фахівець одразу після завершення навчання повинен володіти професійною компетентністю, достатньою не тільки для виконання функціональних посадових обов'язків, а й необхідних для забезпечення обороноздатності держави [1]. Потреба вирішення цього завдання підштовхує нас до розробки принципово нової моделі управління навчальним процесом у ВЗВО, що розкриває механізм формування професійної компетентності майбутнього офіцера НГУ.

Різні аспекти формування професійних якостей упроцесіпрофесійноїпідготовки військовослужбовців підрозділів силових структур розглядались у психологічних дослідженнях Л.М. Балабанової, В.I. Барка, М.С. Корольчука, В.М. Крайнюк, О.А. Матеюка, Л.І. Мороз, В.С. Медведєва, О.Д. Сафіна, Є.М. Потапчука, О.В. Тімченка, М.I. Томчука та ін. Але в більшості досліджень вони обмежуються дослідженням набору професійно-важливих якостей їх формування та оцінки. Залишається незрозумілим, що психологічно означає людина як професіонал, як суб'єкт професійної діяльності, чим психологічно відрізняється професіонал своєї справи від інших людей. В багатьох випадках поєднують поняття професіоналізму з професійною компетентністю в тому числі 3 діяльністю військового.

Отже актуальність даної проблеми полягає в суперечності між необхідністю забезпечити війська НГУ професійно компетентними офіцерами та відсутністю сучасної спеціально розробленої моделі управління формуванням професійної компетентності курсантів у ВЗВО.

Мета статті. На основі аналізу психологопедагогічної літератури систематизувати та поєднати розглянуті в літературі психологічні та педагогічні аспекти професійної компетентності майбутнього офіцера та запропонувати рекомендації 3 формування професійної компетентності майбутніх офіцерів.

Ця мета реалізується вирішенням наступних завдань:

1. Визначити методологічні та теоретичні аспекти професійної компетентності майбутнього офіцера.

2. Поєднати різні підходи розвитку різних сторін професійної компетентності майбутнього офіцера.

3. Запропонувати рекомендації з формування основних аспектів професійної компетентності майбутнього офіцера.

Викладення основного матеріалу. Необхідним складником професіоналізму людини є професійна компетентність. Питання професійної компетентності розглядаються в працях вітчизняних так і в зарубіжних вчених А.В. Шевченка, І.М. Красуцької, Д.Д. Осадчук, Ю.С.Таймасова та інші. Сучасні підходи та трактування професійної компетентності різні. На сьогоднішній день існують тлумачення цього визначення як “поглиблені знання”, “стан адекватного виконання завдань" “здатність до актуального виконання діяльності” то що [1]. Проблема професійної компетентності активно вивчається та досліджується. Часто це поняття використовується для вираження рівня професіоналізму та кваліфікації.

Професійна компетентність розглядається як характеристика якості підготовки фахівця, ефективності трудової діяльності. В педагогічних науках цю категорію розглядають як компонент загальнокультурної компетентності, або рівень освіченості спеціаліста. Якщо спробувати визначити місце компетентності в системі професійної майстерності, то вона знаходиться між старанністю та досконалістю [6, 11 - 12].

Порівнюючи професіоналізм 3 різними аспектами сформованості спеціаліста А.К. Маркова виділяє чотири типи професійної компетентності, а саме [3].

1. Спеціальна або діяльнісна професійна компетентність характеризує володіння діяльністю на високому професійному рівні та включає не тільки наявність знань, а і уміння задіяти їх на практиці.

2. Соціальна професійна компетентність характеризується володіння способами професійної співпраці, прийнятими в професійних співтовариствах.

3. Особистісна професійна компетентність характеризує володінням способами самовираження 


\section{ПСИХОЛОГЧНН ТАПЕДАГОГІЧН АСПЕКТИПРОФЕСЙ̆НОӤ КОМПЕТЕНТНОСТІ МАЙБУТНІХ ОФІЦЕРІВ НАЦІОНАЛЬНОӤ ГВАРДІЇ УКРАЇНИ}

та саморозвитку. Здатність до самостійного прийняття рішень, виявляти суть проблеми.

4. Індивідуальна професійна компетентність характеризується володінням засобами саморегуляції, здатність до професійного росту, наявність професійної мотивації.

В якості основної складової професійної компетентності А.К. Маркова виділяе здатність до саморозвитку, набутті нових знань, вмінь, а також використання їх в практичній діяльності. Дуже цікава ієрархічна модель педагогічної компетентності в якій кожен наступний блок спирається на попередній створюючи фундамент для побудови наступних компонентів [2].

Професійна компетентність формується вже на початку професійної підготовки фахівця. Але якщо навчання у ВЗВО слід розглядати як процес формування основ професійної компетентності, то навчання в магістратурі на оперативнотактичному рівні, то як процес поглибленої професійної компетентності вищих її складових.

У сучасних психолого-педагогічних дослідженнях проблема професійної компетентності займає одне 3 провідних місць, про що свідчать матеріали наукових конференцій, серії статей і монографій, що досліджують сутність і структуру даного феномена, його значення для практичної діяльності з підготовки сучасного фахівця [4, 202 - 210]. Значна увага пов'язана 3 необхідністю формування нових підходів до визначення змісту професійної освіти, розробкою вимог до випускників професійної школи в загальному вигляді для вирішенням актуальних завдань, що стоять сьогодні перед усіма сферами держави та суспільства $[5,16]$.

Аналіз різних підходів до визначення феномена “компетентність” дозволив сформулювати ряд положень, які $є$ основними в розгляді даного поняття:

- компетентність розуміється як базова, інтегральна якість особистості професіонала (І.Б. Міщенко, І.А. Зазюн);

- компетентність розглядається як результат професійної підготовки особистості у вузі, що включає професійне становлення, професійне навчання, професійне виховання (В.В. Ягупов, О.С. Губарева);

- рівень сформованості компетентності визначається змістом і структурою освітнього процесу 3ВО, так само як зміст і структура освітнього процесу залежать від того, що розуміється під компетентністю випускника.

3 позицій даних базових підстав в контексті нашої роботи аналізується поняття “професійна компетентність випускника військового ЗВО”, специфіка якого обумовлена дією загальних, особливих й одиничних вимог до військової служби, а сутність і структура визначаються сформованістю у майбутнього офіцера комплексу якостей, що відповідають вимогам, цілям, завданням і характером сучасної військової служби, до складу якої входять командноорганізаторська, навчальна, виховна та експлуатаційна діяльності.

Професійно компетентний може вважатися випускник ВЗВО, який здатний:

- застосовувати Кодекс честі офіцера, дотримуватись морально-етичних норм поведінки, створювати атмосферу довіри, взаємоповаги, доброзичливості і толерантності у військовому колективі, діяти соціально відповідально та свідомо, дотримуватись правил військового етикету;

- аналізувати і прогнозувати суспільні явища й процеси, виділяти нормативно-правові засади забезпечення національної безпеки України, питання правового регулювання ведення збройної боротьби;

- адаптуватись до швидких змін обстановки та діяти в новій ситуації;

- демонструвати творче та гнучке мислення, здатність до самооцінки, наполегливість, активність, комунікабельність, стресостійкість, навички самоконтролю, особисту мотивацію на військову службу;

- застосовувати психолого-педагогічні основи управлінської та виховної діяльності, методи психодіагностики особистості, вивчення соціально-психологічних явищ у військових колективах, контролювати стан військової дисципліни, здійснювати морально-психологічне забезпечення і мотивувати особовий склад під час виконання завдань за призначенням;

- спілкуватися державною мовою як усно, так і письмово;

- спілкуватися іноземною мовою за професійним спрямуванням;

- спілкуватися та працювати в команді 3 представниками інших професійних груп різного рівня, $з$ військовослужбовцями 3 інших країн, беручи до уваги різні термінологію, знання та розуміння своїх колег з відповідних питань;

- володіти достатніми знаннями і розумінням сутності та основних питань етики збройної боротьби, визначення універсальних моральних норм в аспекті поведінки учасників збройної боротьби;

- аналізувати складні питання історії, закономірності, тенденції та проблемні питання розвитку культури України в їх діалектичному взаємозв'язку; 


\section{ПСИХОЛОГІЧНІ ТАПЕДАГОП ГЧНІ АСПЕКТИПРОФЕСІЙНОӤ КОМПЕТЕНТНОСТІ МАЙБУТНІХ ОФЩЕРІВ НАЦІОНАЛЬНОӤ ГВАРДІЇ УКРАЇНИ}

\begin{abstract}
- знати та розуміти правові засади функціонування держави, основи законодавства України; системи забезпечення національної безпеки України та основні принципи їі функціонування; структуру сектору національної безпеки та оборони держави, особливості функціонування і взаємодії його складових; основи міжнародного права, структуру міжнародних організацій та основи їх діяльності в умовах інтеграційних процесів;

- знати та розуміти процеси управління підрозділом (за видами, родами Збройних Сил України, інших військових формувань, утворених відповідно до законів України) в ході підготовки і ведення бою та у повсякденній діяльності;

- планувати, організовувати і застосовувати навички ведення бою підрозділом (за видами, родами Збройних Сил України, інших військових формувань, утворених відповідно до законів України);
\end{abstract}

- застосовувати штатне озброєння та військову техніку підрозділу (за видами, родами Збройних Сил України, інших військових формувань, утворених відповідно до законів України), знати його тактико-технічні характеристики;

- знати та розуміти процеси всебічного забезпечення підрозділу (за видами, родами Збройних Сил України, інших військових формувань, утворених відповідно до законів України) в ході бойового застосування та повсякденної діяльності;

- демонструвати навички захисту себе i забезпечення захисту особового складу, озброєння та військової техніки підрозділу (за видами, родами Збройних Сил України, інших військових формувань, утворених відповідно до законів України) в бою; Підтримувати сприятливий морально-психологічний клімат і психологічно готувати особовий склад підрозділу до дій в екстремальних умовах;

- підтримувати озброєння та військову техніку в постійній готовності до виконання завдань за призначенням, здійснювати водіння та технічне обслуговування базових машин підрозділу (за видами, родами Збройних Сил України, інших військових формувань, утворених відповідно до законів України), організовувати підготовку їх до маршу;

- працювати автономно та в команді, виконуючи обов'язки за посадою.

Перелічені вимоги дозволяють в структурі професійної компетентності випускника ВЗВО виділити дві основні складові:

1. Когнітивно-операційну, яка відображатиме “стратегію” військової служби і включає в себе: військово-професійні знання, вміння і навички, які $€ з$ одного боку, передумовами успішної діяльності майбутнього офіцера, а 3 іншого новоутвореннями (вони самі розвиваються i збагачуються знаннями в ході навчання і служби майбутнього фахівця);

2. Професійно-особистісну, об'єднуючу інтегральні характеристики особистості, що формується і включає професійну самосвідомість, індивідуальний стиль діяльності і спілкування, творчий потенціал майбутнього військового фахівця.

Необхідно відзначити, що в структурі професійної компетентності випускника ВЗВО обидві складові знаходяться в складних діалектичних відносинах, які проявляються в тому, що кожна з них є передумовою, то засобом, то результатом розвитку іншої (наприклад, на початку професійно-особистісна складова $є$ умовою, пристосовується до вимог когнітивноопераціонально складової, а потім сама будує і розвиває іiі).

Отже професійна компетентність випускника ВЗВО розуміється нами як базова, інтегральна характеристика особистості сучасного офіцерафахівця, що проявляється у високому рівні професіоналізму, здатності до ефективного виконання бойових завдань і обов'язків за функціональним призначенням у військах.

Висновок. Служба офіцера є відповідальним та дуже складним видом професійної діяльності. Кожен офіцер працює з солдатами напряму, будучи вихователем та своїм прикладом, знаннями та уміннями, відношенням до служби кожен день виховує особовий склад.

Професіоналізм офіцера впливає на боєготовність військ та безпеку нашої держави. Офіцер - це професійно-компетентний у військовій та психологопедагогічній справі фахівець, який вміє передавати на високому рівні професійні знання, уміння, навички виховувати доручений йому особовий склад на відповідному рівні, який вимагає сьогодення.

Професійна майстерність офіцера досягається шляхом активної роботи, працелюбністю, відданістю своїй справі та самовдосконаленням.

\section{ЛІТЕРАТУРА}

1. Бухун А.Г. Розвиток громадянськоӥ компетентності майбутніх офіцерів Національної гвардії України у процесі професійної підготовки: дис. ... канд. пед. наук : (13.00.04); Полтав. нац. пед. ун-т імені В. Г. Короленка. Полтава, 2017.

2. Дьомін У. А. Професійна компетентність фахівця: поняття і різноманітні види. Стандарти i моніторинг освіти. №4. 2000. 


\section{ПСИХОЛОГІЧНІ ТАПЕДАГОГІЧНІ АСПЕКТИПРОФЕСІЙНОӤ КОМПЕТЕНТНОСТІ МАЙБУТНІХ ОФІЦЕРІВ НАЦІОНАЛЬНОЇ ГВАРДІЇ УКРАЇНИ}

3. Маркова А. К. Психология профессионализма. Москва, 1996. С. $202-217$.

4. Машталер А.М. Розвиток професійної компетентності офіцерів прикордонників у системі підвищення кваліфікації засобами дистанційного навчання: автореферат дис. ... канд. пед. наук: 13.00.04; Держ. прикордон. служба України, Нац. акад. Держ. прикордон. служби України ім. Богдана Хмельницького. Хмельницький, 2016. 16 с.

5. Павлюк Є.О. професійна компетентність як складова професійної діяльності майбутніх тренерів-викладачів. Серія педагогічні та психологічні науки: зб.наук.прац./ред. кол: док. в. н. проф. Б.М. Олексієнко(голов.ред.) та інші; Хмельницький, 2014. №2(75). с.111-114.

6. Турчинов А.В. Формуванняздоров'язбережувальної компетентності майбутніх офіцерів Національної гвардії України у процесі професійної підготовки: дис. ... канд. пед. наук : (13.00.04) Хмельницький, 2017.

\section{REFERENCES}

1. Bukhun, A.H. (2017). Rozvytok hromadianskoi kompetentnosti maibutnikh ofitseriv Natsionalnoi hvardii Ukrainy u protsesi profesiinoi pidhotovky [Development of civil competence of future officers of National Guard of Ukraine is in the process of professional preparation]. Candidate's thesis. Poltava V.G. Korolenko National Pedagogical University. Poltava. [in Ukrainian].
2. Domin, U. A. (2000). Profesiina kompetentnist fakhivtsia: poniattia i riznomanitni vyd $y$ [Professional competence of specialist : concept and variouskinds]. Standards and monitoring. No. 4, pp.3442. [in Ukrainian].

3. Markova, A. K. (1996). Psykholohyia professyonalyzma [Psychology of professionalism] Znanye, pp.202 - 217. [in Russian].

4. Mashtaler, A.M. (2016). Rozvytok profesiinoi kompetentnosti ofitseriv prykordonnykiv u systemi pidvyshchennia kvalifikatsii zasobamy dystantsiinoho navchannia [Development of professional competence of officers of border guards is in the system of inplant training byfacilities controlled from distance studies]. Extended abstract of candidate's thesis. Khmelnytskyi, 16 p. [in Ukrainian].

5. Pavliuk, Ye.O. (2014). Profesiina kompetentnist yak skladova profesiinoi diialnosti maibutnikh trenerivvykladachiv [Professional competence as a component of professional activity of future trainersteachers]. Series of pedagogical and psychological sciences. Khmelnytskyi. No. 2(75), pp. 111-114 p. [in Ukrainian].

6. Turchyno, A.V. (2017). Formuvannia zdoroviazberezhuvalnoi kompetentnosti maibutnikh ofitseriv Natsionalnoi hvardii Ukrainy u protsesi profesiinoi pidhotovky [Formation of health-saving competence of future officers of the National Guard of Ukraine in the process of training]. Khmelnytskyi. [in Ukrainian].

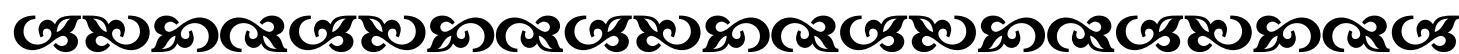

"Я не думаю, що є яқась інша яқість настільки жістотна для будь-яқого виду успіху, якнаполегливість".

Dжон Февісон Роқбеллер американський підприємеиь та благодійник

“Наші знання - це сума того, чого ми навчилися, й того, що ми забули".

Марія бон Ебнер-Ешенбах австрійсьқа письменниия

"Будь-яқе навчання людини, є не що інше, як мистеитво сприяти прагненню природи до свого власного розвитку".

گ̆оганн Тенріх Тесталоииі швейцарський педагог

“Найбільш приємніші для нас ті слова, яқі дають нам яқе-небудь знання".

Apicmoтель давньогреиький фбілособ

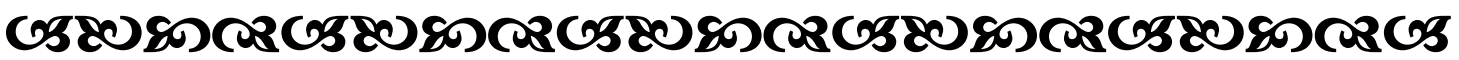

